\title{
Parasitizations Levels and Temperature Tolerance of Rice Bug (Leptocorisa oratorius Fabricius) Egg Parasitoids: Mass Rearing for Biological Control
}

\author{
Fri Maulina ${ }^{\#}$, Novri Nelly ${ }^{*}$, Hidrayani ${ }^{*}$, Hasmiandy Hamid ${ }^{*}$ \\ ${ }^{\#}$ Department of Food Crop, Agricultural Polytechnic of Payakumbuh. West Sumatra. 26271. Indonesia/Student of Agriculture Science Study \\ Program Post Graduate, Andalas University. \\ E-mail : maulinafri@yahoo.co.id
}

*Department of Plant Protection, Agriculture Faculty. Andalas University. Padang. West Sumatra. 25163. Indonesia

E-mail: novrinelly@yahoo.com, hidrayani @yahoo.com, hasmiandyhamid@gmail.com

\begin{abstract}
The rice bug is a significant pest that attacks wet rice fields Rice bug egg parasitoids can be used as a biological control for this pest in the field. Successful parasitoid mass rearing in the laboratory depends on optimum temperatures to ensure the fitness of the adults that are introduced into the field. The objectives of this research were to determine the parasitization levels of rice bug egg parasitoids from two areas in West Pasaman Regency; one in the lowlands (Kinali $56 \mathrm{~m}$ asl) and the one at a higher altitude in the foothills (Talamau $47 \mathrm{~m}$ asl). Then the best temperature for parasitoid rearing was determined for the dominant parasitoid. A purposive sampling method was used for collecting the rice bug egg samples which were collected along $1 \mathrm{~km}$ transect lines in the rice fields. A descriptive method was used to report the parasitization levels. Rearing temperature treatments for the dominant rice bug egg parasitoids in the laboratory were $20^{\circ} \mathrm{C}, 25^{\circ} \mathrm{C}, 30^{\circ} \mathrm{C}$ and one batch raised as a control with no temperature regulation. 20 replications were conducted for each treatment. The data were analyzed using Completely Randomized Design (Statistics 8). The main species of rice bug egg parasitoids found were Hadronotus leptocorisae and Ooencyrtus malayensis with parasitization levels in the lowlands of $6.4 \%$ and $2.2 \%$ and the foothills of $28.4 \%$ and $3.1 \%$ respectively. The best temperature for mass rearing parasitoid in the laboratory was $25^{\circ} \mathrm{C}$, and they had the longevity of $22.6 \pm 5.4$ days.
\end{abstract}

Keywords - egg parasitoid; Hadronotus leptocorisae; Ooencyrtus malayensis; parasitization; temperature; rice bug

\section{INTRODUCTION}

The effectiveness of parasitoids as pest control is determined by the level of parasitization. This in turn is influenced by biotic factors such as the size of parasitoids [1], the age of parasitoids, host density [2], and abiotic factors such as temperature [3],[4], relative humidity, rainfall [3],[5], and intensity of light [3]. Use of parasitoids as a biological control agent of rice/stinky bugs Leptocorisa oratorius Fab. (Hemiptera : Alydidae) in West Pasaman Regency, West Sumatra has not been studied although this pest is endemic in the area and effects every crop and can cause up to $50 \%$ yield loss. This pest attack always happens every year (2009-2014) so that if the climatic conditions support an explosion of the population will arise. Grains attacked during the milky stage of growth become empty husks, decreasing the quality and quantity of hulled rice [6].

Generally, farmers use synthetic insecticides to control this insect which can increase insecticide resistance, and lead to the extinction of natural enemies, leave a toxic residue in the hulled rice, and in the environment. One less problematic control is using naturally occurring parasitoids to attack the rice bug eggs. The parasitoids that have been found in eggs of rice bugs include Agrion sp or Hadronotus leptocorisae [7],[8] and Ooencyrtus sp [9],[10], but nature of the rice bug egg parasitoids in the area of West Pasaman Regency, West Sumatra is still unknown. Discovering the species of rice bug egg parasitoids that occur in an area is the first step to determining whether they could be used for biological control there. These rice bug egg parasitoids can then be reared in large numbers in the laboratory and tested in the field. If successful, continued mass rearing in a controlled environment could lead to these parasitoids becoming a sustainable biological control agent.

Previous researchers in Bandung, West Java [7] have found that the females of $H$. leptocorisae egg parasitoid prefer to lay eggs in 0-1 day old rice bug eggs. The female parasitoid appears to be able to detect which of the rice bug eggs are more likely to provide a favorable outcome for their 
progeny select them over younger eggs. Its behaviour associated with confidence of the parasitoid female to its survival.

Temperature influences the development of both adult and juvenile parasitoids and determines the success of mass rearing activity in the laboratory. Temperature models have been developed for Eriborus arganteopilosus parasitoid in Crocidolomia pavonana larvae [4], and Ooencyrtus nezarae parasitoid in Riptortus linearis eggs [11] to determine optimum temperature for the development of the parasitoid and so maximize the effectiveness and efficiency of mass rearing. This model can predict the growth rate and development of the parasitoid at different temperatures. [12] has succeeded in using temperature control to extend the longevity of the larvae stage of Eretmocerus mundus parasitoids before they are released into the field. Methods to predict tolerance limits for production of Oobius agrili, Spathius agrili and Tetrastichus planipennisi parasitoids that are fit to be released at particular locations including the lower limits of temperature tolerance have been developed. [13]. Developmental durations Aphelinus varipes (Forster) parasitoid at mummies of Aphis glycines decreased with increasing temperatures [14].

In this study, the level of parasitization of the dominant species in rice bug eggs and the influence of temperature on natality rates of the adult parasitoid in the laboratory is investigated. Information from this study can be used to plan strategic of mass rearing of the dominant parasitoid in rice bug eggs. The objectives of this research were to determine the parasitization levels of rice bug egg parasitoids from two altitudes in West Pasaman Regency and to determine the best temperature for rearing these parasitoids in the laboratory.

\section{MATERIAL AND METHOD}

\section{A. Collecting of Samples}

The locations were sampled using purposive sampling and the rice bug eggs samples were collected along $1 \mathrm{~km}$ transect lines in rice fields. The criteria for choice of locations were an area around 3-5 ha and rice at the milk stage of development. The locations of research were in the lowland (Kinali $56 \mathrm{~m}$ asl) and foothills (Talamau $547 \mathrm{~m}$ asl) (Fig.1). The rice bug eggs were removed from rice leaves and placed in a test tube with a lid $(1 \mathrm{~cm}$ of diameter and 7 $\mathrm{cm}$ in length), and labeled.

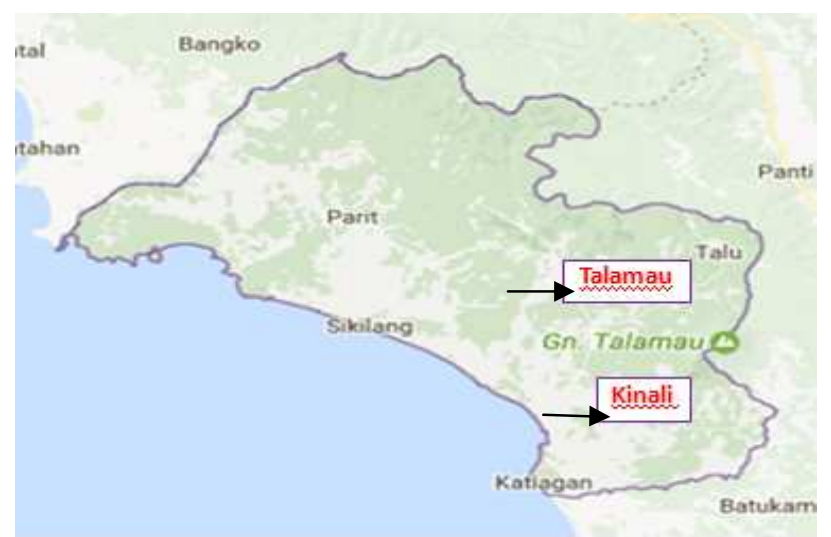

Fig. 1 Location sample of the rice bug eggs from different locations in West Pasaman, West Sumatra
The collected eggs were studied in the Insect Bioecology Laboratory, Plant Protection Department of Andalas University (220 m asl, relative humidity 85\%-90\%) from April 2016 until June 2016. A descriptive method was used to characterize parasitization, mortality and natality levels. The dominant species of parasitoid was identified and subsequently tested for survival at different temperatures using Completely Randomized Design (Statistics 8) and 20 replications with temperatures of $20^{\circ} \mathrm{C}, 25^{\circ} \mathrm{C}, 30^{\circ} \mathrm{C}$, and one batch raised as a control with no temperature regulation.

\section{B. Observation in Laboratory}

The samples were collected and placed in one small test tube $(1 \mathrm{~cm}$ diameter) per leaf with a single cluster of eggs in each test tube. We identified each of the parasitoids that emerged under a binocular microscope Carton SPZ50 [8] [15] [16]. Once the dominant parasitoid was identified and the parasitization level measured. Temperature tolerance was tested for this species, feeding them drops of honey on the inside of the test tube and observing them daily over their full lifespan.

\section{Data Analysis}

The data were calculated as follows:

1) Parasitization Levels

$$
\frac{A}{B} \times 100 \%
$$

Notes:

$\mathrm{P}=$ Parasitization levels

A = Number of parasitoid eggs (emerging as

the healthy parasitoid, not emerging or abnormal)

$\mathrm{B}=$ Number of rice bug eggs in the sample

\section{2) Mortality of Parasitoid}

Notes:

$$
\mathrm{M}=\frac{\mathrm{Pm}}{\mathrm{Tp}} \times 100 \%
$$

$\mathrm{M}=$ Mortality rate of parasitoids

$\mathrm{Pm}=$ Number of dead parasitoids (unable to emerge)

$\mathrm{Tp}=$ Total number of parasitoids

\section{RESUlTS AND DISCUSSIONS}

\section{A. Parasitization Level of Rice Bug Egg Parasitoids}

Two parasitoid species were identified in both research locations ; Hadronotus leptocorisae and Ooencyrtus malayensis. H. leptocorisae being more dominant both in lowland areas at $6.5 \%$ parasitization levels and in the foothills at $28.4 \%$. Parasitization levels of $O$. malayensis at these sites were $3.1 \%$ and $2.21 \%$, respectively. $H$. leptocorisae has been also found to be the dominant parasitoid in rice bug eggs at other West Sumatra locations i.e; at Pariaman Regency [17], Agam Regency [18], and Tanah Datar Regency [19].

It appears that $H$. leptocorisae thrives better in higher altitudes although these figures may also be influenced by the number of rice bug eggs which was higher in the foothills (451 eggs along a $1 \mathrm{~km}$ transect) than the lowlands (362 eggs along a similar transect) (Table I). 
TABLE I

Parasitization LeVel of Parasitoid In Rice BUg Eggs on PADDy CROP IN WeSt PASAMAN REGENCY, WEST SUMATRA

\begin{tabular}{|c|c|c|c|c|}
\hline $\begin{array}{l}\text { Location } \\
\text { (Subdistrict } \\
\text { /District) }\end{array}$ & $\begin{array}{l}\text { Altitude } \\
\text { (m asl) }\end{array}$ & $\begin{array}{l}\text { Number of Eggs } \\
\text { (eggs) }\end{array}$ & $\begin{array}{c}\text { Parasitization of } \\
\text { Hadronotus leptocorisae* } \\
(\%)\end{array}$ & $\begin{array}{c}\text { Parasitization of } \\
\text { Ooencyrtus malayensis } \\
(\%)\end{array}$ \\
\hline Wonosari/Kinali & $\begin{array}{c}56 \mathrm{~m} \text { asl (low } \\
\text { land) }\end{array}$ & 362 & $6.50 *$ & 3.10 \\
\hline $\begin{array}{l}\text { Banjar } \\
\text { Kuning/Talamau }\end{array}$ & $\begin{array}{c}547 \mathrm{~m} \text { asl } \\
\text { (middle land) }\end{array}$ & 451 & $28.40^{*}$ & 2.21 \\
\hline
\end{tabular}

Note: *The dominant egg parasitoid in West Pasaman Regency, West Sumatra

The same case was reported by [20] discovered that with Diaeretiella rapae and Apidius sp, parasitoids of Lipaphis erysimi, high populations of insect host in the field led to higher parasitization levels. Recent laboratory research in North Sumatra [2] indicated that the levels of parasitization of the parasitoid Xanthocamploplex sp were influenced the population density of the host (Chillo sacchariphagus larvae). The highest level of parasitization observed in [2] was $55 \%$. Parasitization levels are reported to be influenced by the availability of a supportive environment for the development of the parasitoid, among others, the existence of other plants that can provide temporary sustenance when the conditions are not conducive main host plant. [21] found the existence of the Arachis pintoi or Ageratum conyzoides plants around a starfruit tree increased Fobius sp parasitization of Bactrocera carambolae fruit flies.

The natality of $H$. leptocorisae that oviposited in the field was found to be lower than in the laboratory. Mortality is higher in the lowland eggs (87\%) compared to the foothills (43\%) (Fig. 2). This further reinforces the notion that the $H$. leptocorisae parasitoid requires relatively low temperatures to thrive. Incidentally, temperatures were below average the time of sampling (April 2016) due to rainfall with precipitation at each of these locations being $334 \mathrm{~mm}$ and $438 \mathrm{~mm}$ respectively over this three month period (Table II).

Rice bug eggs are strongly attached (Fig.3) to the surface of the rice leaves (a) even during rain. More the eggs adhering [22] in leaf cause glue images (b). Nymph or adult rice bugs on the rice plants are not so well protected and washed away by heavy rains causing high mortality just as has been observed in thrips and aphids on lettuce crops [25]. In fact, parasitoids appear to thrive in the lower temperatures that accompany rainy periods. Many adult parasitoids die as they attempt to exit the host eggs (Fig.4). Even perfectly formed adults were observed partial emerged from chorion but become stuck and eventually died (a), sometimes only one new antenna emerges before death (b). The ovipositor of this parasitoid is visible indicating that the body of a mature adult has been completely formed. The observations under a binocular microscope showed that there is no difference the morphology of the adult of $H$. leptocorisae parasitoid between the live specimens and those who die the eggs of the rice bug.

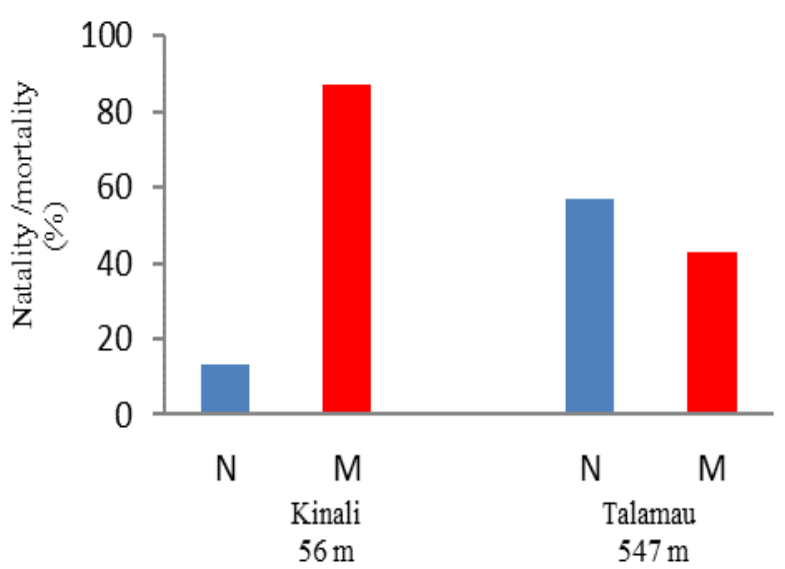

Fig. 2 Comparison of natality and mortality of Hadronotus leptocorisae egg parasitoids in the laboratory in rice bug eggs from different locations in West Pasaman, West Sumatra

A previous study [2] has shown that in the host egg Chillo sacchariphagus the quality and quantity of nutrients in the host larvae determines the success of the emergence of adult Xanthocampoplex sp. parasitoid. But, in this case, the condition of the nutrients in the $L$. oratorius eggs in this study is thought to be sufficient for the growth and development of the $H$. leptocorisae as the parasitoids are perfectly formed as shown in figure 4 .

Presumably, there are abiotic factors that influence the ability of adult parasitoids to emerge from the host eggs. Parasitoid oviposition and development to adulthood of $\mathrm{H}$. leptocorisae has been found to be more successful when the host eggs are aged 0-1 days [7] as at this stage the egg is incompletely formed and has poor body defense systems that hinder emergence. There is not true for all parasitoids. Xanthocamploplex sp parasitoids have been shown to be more likely to be successful in infecting a 5-day old host [2], was higher during the time of the study (Table II). The temperature at this cooler location appears to be more suitable for the development of the parasitoid. The inability of adult parasitoid to emerge may also be influenced by temperature. Temperature is one of the factors that influence the development of the parasitoid (Trissolcus spp) on the host (Eurygaster integriceps), especially on a lifespan and oviposition period [5]. 
TABLE II

Mortality RELATIONSHIP WITH THE APPEARANCE OF HADRONOTUS LEPTOCORISAE EgG PARASITOIDS (DOMINANT PARASITOID) IN WeSt PASAMAN, WeSt SUMATRA

\begin{tabular}{|c|c|c|c|c|c|}
\hline \multirow{2}{*}{$\begin{array}{c}\text { Locations } \\
\text { (Sub- } \\
\text { district/District) }\end{array}$} & \multirow{2}{*}{$\begin{array}{l}\text { Altitude } \\
\text { (m asl) }\end{array}$} & \multirow{2}{*}{$\begin{array}{c}\text { Rainfall } \\
(\mathbf{m m}) \\
*\end{array}$} & \multicolumn{2}{|c|}{ Egg Condition Pasca Oviposition } & \multirow{2}{*}{$\begin{array}{c}\text { Presentation of } \\
\text { Emerge } \\
(\%)\end{array}$} \\
\hline & & & Un Emerge & Emerge & \\
\hline Wonosari / Kinali & $\begin{array}{c}56 \text { m asl (low } \\
\text { land) }\end{array}$ & 334 & 20 & 3 & 13.0 \\
\hline $\begin{array}{c}\text { Banjar Kuning/ } \\
\text { Talamau }\end{array}$ & $\begin{array}{c}547 \mathrm{~m} \text { asl } \\
\text { (middle land) }\end{array}$ & 438 & 55 & 73 & 52.9 \\
\hline
\end{tabular}

Note: *Rainfall on April 2016

Temperature has found to influence the abiltiy of Eriborus argenteopilosus (Hymenoptera : Ichneumonidae) parasitoid to emerge from Crocidolomia pavonanna (Lepidoptera : Pyralidae) larvae [4]. Temperature also affects the growth and survival rate of adult E. argenteopilosus parasitoids which are more likely to emerge successfully at temperatures near $20 \mathrm{oC}$. At temperatures much higher or much lower than $20 \mathrm{oC}$ the larvae do not develop in the pupae leaving the pupae empty.

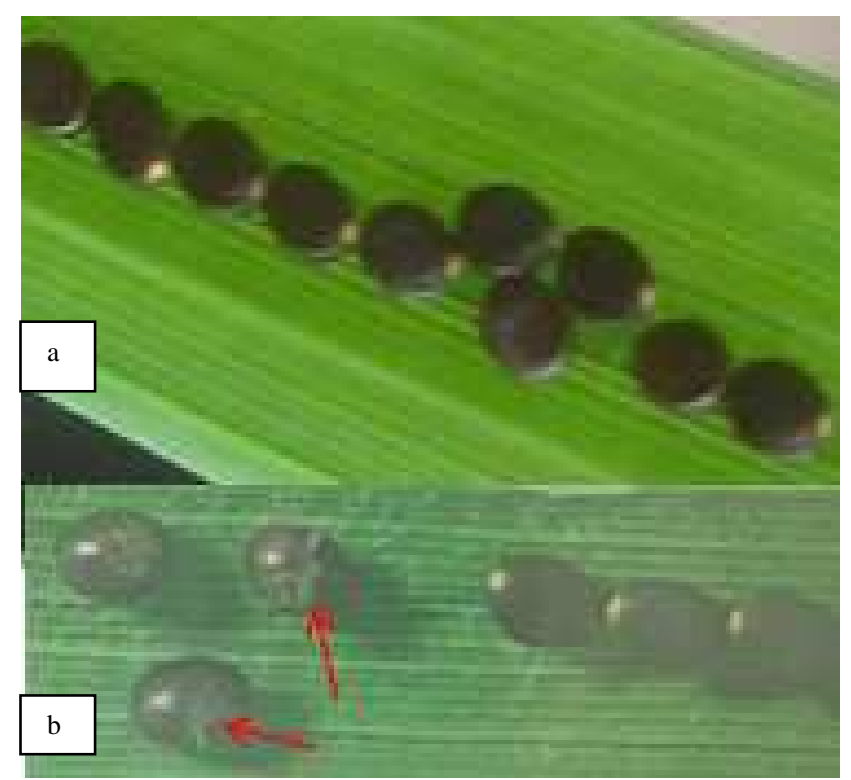

Fig. 3 The rice bug eggs adhering in paddy leaf: a. Eggs neatly arranged on the leaves, b. there is glue on the surface under the egg

\section{B. Tolerance of Hadronotus leptocorisae Adult Parasitoids Towards Temperature}

The relationship between temperature, parasitization levels and emergence percentage of $H$. leptocorisae was investigated using temperatures of $20^{\circ} \mathrm{C}, 25^{\circ} \mathrm{C}, 30^{\circ} \mathrm{C}$, and uncontrolled room temperature. Results indicate that $25^{\circ} \mathrm{C}$ maximises longevity resulting in a lifespan of $22.6 \pm 5.4$ days which is significantly longer than at other temperatures tested (Fig.5) indicating this is the temperature at which the adult parasitoid thrives best. The $25^{\circ} \mathrm{C}$ temperature treatment (B) gives a longevity significantly better than any other treatment. This longevity indicates optimum conditions for the development of the H. leptocorisae adult parasitoid.
The new result of reasearch [26] showed that the survival of the egg of $H$. leptocorisae until adulthood in this temperature was high $(68.2 \%)$.

The highest insect activity also occurs at this temperature. The optimum temperature needed by adult parasitoids is dependent on species. The Aphelinus asychis (Walker) parasitoid (Hymenoptera : Aphididae) of Aphis gossypii (Glover) (Sternorrhyncha : Aphididae ) can adapt to temperatures in the range $18-30^{\circ} \mathrm{C}$, but reproduces better when the temperature is close to $25^{\circ} \mathrm{C}$ [3]. Aenasius bambawalei (Hayat) (Hymenoptera : Encyrtidae) parasitoid of Phenacoccus solenopsis (Tinsley) (Hemiptera : Pseudococcidae) thrives up to $27^{\circ} \mathrm{C}$ [22]. Parasitization levels of Trissolcus semistriatus (Nees) in Eurygaster integriceps (Put) is positively correlated with temperature up to $20^{\circ} \mathrm{C}$ [6]. Temperature greatly affects the parasitization success of Eriborus argenteopilosus [4]. Temperature affects the intensity of the parasitoid's activity in locating and parasitizing the host. [24] showed that, along with density of the host, a temperature of $25^{\circ} \mathrm{C}$ is best for parasitoid success E. argenteopilosus in Crocidolomia pavonana larvae. According to [25] temperature is the driving force behind insect development, growth and behavior. The local weather pattern a significant impact on the abundance in an insect in our crops.

According to [3] the short development time, high female to male ratio, long life span, and high fecundity, and temperature tolerance are indications that a parasitoid may be useful as a biological control agent. These features are that are seen in $\mathrm{H}$. leptocorisae. Using a parasitoid for biological control requires prior mass rearing in a laboratory and selecting the time of introduction into the field when the environmental factors are most favorable. To provide optimal laboratory conditions for this mass rearing of a parasitoid in-depth study must be conducted including the relationship between temperature and other abiotic factors and the growth and reproduction of the parasitoid.

The insect's longevity is sensitive to environmental variation. The number of eggs a parasitoid can oviposite on the host eggs depends on longevity. The longevity of adult of $\mathrm{H}$. leptocorisae egg parasitoid is maximum at $25^{\circ} \mathrm{C}$ (constant temperature) but the ideal values of other abiotic factors such as humidity are yet to be determined. Oviposition is most effective when the host eggs are aged 0-1 days as at this stage the adult parasitoids are more likely to emerge successfully. 

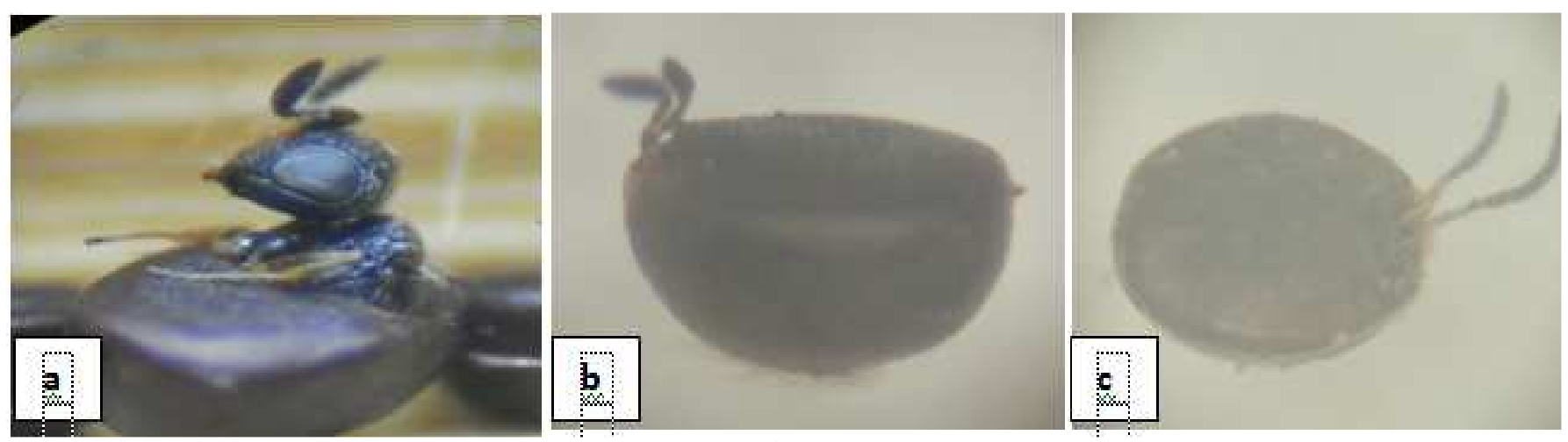

Fig. 4 The adult of Hadronotus leptocorisae parasitoids a. Unable emerge from the rice bug eggs b. Female antenna emerged but the body trapped c. Male antenna but the body trapped

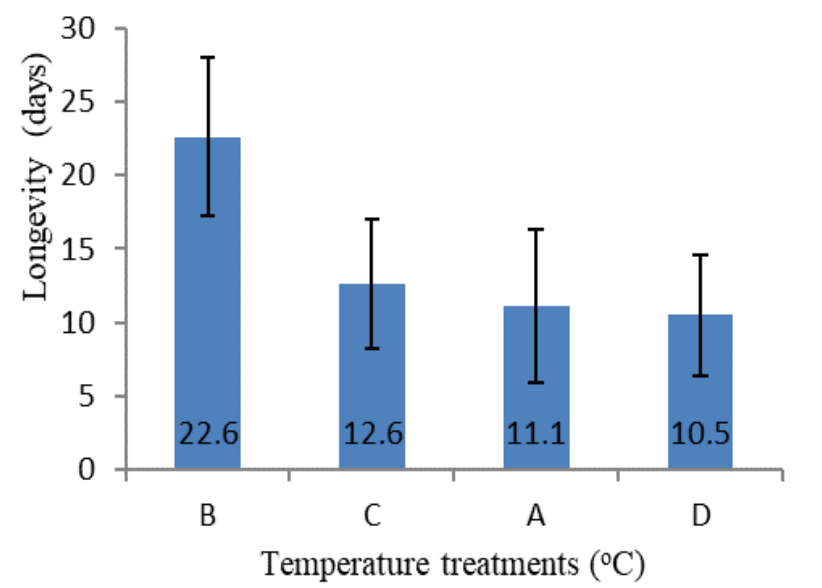

Fig. 5 Effect of temperature for the longevity of Hadronotus leptocorisae parasitoids in laboratory

H. leptocorisae as the dominant rice bug egg parasitoid in West Pasaman Regency is a potential agent for biological control for rice bugs as part of an integrated pest management system as has been achieved in the Philippines. Understanding of local weather conditions before introduction of the egg parasitoids that have been mass reared in laboratory conditions will maximize impact. The use of weather prediction tools such as CC-IS technology that provides recommendations for planting and cropping times would aid with this.

\section{CONCLUSION}

H. leptocorisae was found to be the dominant rice bug egg parasitoid present West Pasaman Regency. Comparison of a lowland location and another in the foothills indicate it appears to thrive better in higher altitudes and at lower temperatures. Oviposition in young host eggs led to a higher survival rate of the adult parasitoid which often died when emerging from older host eggs. The optimum temperature for laboratory raising of this parasitoid for biological control was found to be $25^{\circ} \mathrm{C}$ as at this temperature the adult parasite had an average lifespan of $22.6 \pm 5.4$ days. As an indigenous natural enemy, it could play a larger role in an integrated pest management system of rice bug pests in West Pasaman and other similar tropical rice growing areas.

\section{ACKNOWLEDGMENT}

We would like to thanks to the Director General of Higher Education that gave me BPPDN scholarships with contract number 8222/A4.2/KP/2015, so this research had been done as well. The author would like to thank all those who helped fulfilled the research process is particularly the students in the collected sampling of rice bug eggs in West Pasaman paddy field and laboratory technicians of Insect Bioecology Laboratory of Agriculture Faculty, Andalas University, Padang, West Sumatra.

\section{REFERENCES}

[1] P.A. Eliopoulus, J.A.Harvey, C.G. Athanassiou, and G.J. Stathas, "Effect of biotic and abiotic factors on reproductive parameters of the synovigenic endoparasitoid Venturia canescens," J. Physiological Ent., Vol 28, pp. 268-275, 2003.

[2] L. Silitonga, M.C. Tobing, L.Lubis, "The influence of age and inoculation time parasitoids Xanthocampoplex sp. (Hymenoptera : Ichneumonidae) on number of larvae Chilo sacchariphagus Bojer (Lepidoptera : Crambidae) in laboratory ,“ J. Agroekoteknologi, Vol. 3, pp. 87-98, 2015.

[3] S. Schirmer, C. Sengoonca, and P. Blaeser, "Influence of abiotic factors on some biological and ecological characteristics of the aphid parasitoid Aphelinus asychis (Hymenoptera : Aphelinidae) parasitizing Aphis gossypii (Stenorrhyncha : Aphididae)," Eur. J. Entomol., Vol. 105, pp. 121-129, 2008.

[4] N. Nelly, T. Habazar, R. Syahni, and D. Buchori, “ Pengaruh suhu terhadap perkembangan pradewasa parasitoid Eriborus argenteopilosus Cameron (Hymenoptera : Ichneumonidae)," J. Natur Ind., Vol. 13, pp. 250-255, 2009.

[5] M. Islamoglu, and S. Tarla, "Effects of some abiotic factors on parasitism rate of Eurygaster integriceps Put. (Heteroptera : Scutelleridae) Eggs," J. Romanian Agr. Res., Vol. 31, pp. 331-336, 2014.

[6] BPTPH [Balai Perlindungan Tanaman Pangan dan Hortikultura], "Laporan Tahunan Balai Perlindungan Tanaman Pangan dan Hortikultura," BPTPH Padang, 2013.

[7] T. Anggraeni, A. Jamili, and Umrah, "Perilaku dan penentuan oviposisi telur Hadronotus leptocorisae (Hymenoptera) pada telur hama bulir padi Leptocorisa acuta (Hemiptera)," J. Biocelebes, Vol. 4, pp. 76-79, 2010.

[8] A. Jamili, and T. Anggraeni, "Sex ratio parasitoid telur Hadronotus leptocorisae (Hymenoptera: Scelionidae) pada telur Leptocorisa acuta (Hemiptera: Alydidae) muda dan dewasa," J. Agroteksos, Vol. 22, pp. 50-57. 2012

[9] G.C. Jahn, I. Domingo, M. Liberty, P. Almazan, and J. Pacia, "Effect of rice bug Leptocorisa oratorius (Hemiptera : Alydidae) on 
rice yield, grain quality and seed viability," J. Economic Entom., Vol. 97, pp. 1932-1927, 2004

[10] Rosita, "Kebugaran dan kemampuan reproduksi parasitoid telur Ooencyrtus malayensis Ferr. (Hymenoptera: Encyrtidae) pada dua spesies serangga inang", Tesis, Institut Pertanian Bogor, Indonesia, 2005

[11] K..S.D. Aung, and T. Ueno, "Effect of Temperature on Lifetime Reproduction of the Egg Parasitoid Ooencyrtus nezarae (Ishii) (Hymenoptera: Encyrtidae)," J. Fac. Agr., Vol 56, pp 67-70, 2011.

[12] Sudarjat, "Pengaruh lama penyimpanan pupa parasitoid Eretmocerus mundus (Hymenoptera : Aphelenidae) pada suhu rendah terhadap kebugarannya," J. Bionatura, Vol. 14, pp 25-35 , 2011.

[13] A.A. Hanson, "Cold tolerance of emerald ash borer parasitoids: Oobius agrili Zhang and Huang (Hymenoptera: Encyrtidae), Spathius agrili Yang (Hymenoptera: Braconidae), and Tetrastichus planipennisi Yang (Hymenoptera: Eulophidae)," Retrieved from the University of Minnesota Digital Conservancy, http://purl.umn.edu/156697, 2013

[14] K. Yasuma, and T. Murai, "Development and Reproduction of a Potential Biological Agent, Aphelinus varipes (Hymenoptera : Aphelinidae) at Different Temperatures," J. Appl. Entomol. Zool., Vol. 48, pp 21-26, 2013.

[15] CSIRO [Commenwealth Scientific and Industrial Research Organisation], The insect of Australia, Victoria, Carlton: Melbourne University Press, 1991, Vol. II.

[16] D.J. Borror, C.A.Triplehorn, N.F. Johnson, Pengenalan Pelajaran Serangga, 6th Ed., Yogyakarta: Gadjah Mada University Press, 1996.

[17] F. Maulina, N. Nelly, Hidrayani, and H. Hamid, "Potensi pengembangan parasitoid telur walang sangit (Leptocorisa oratorius F.) di Kabupaten Padang Pariaman," in Proc. Semnas. kebijakan dan pengembangan teknologi hilirisasi dalam upaya peningkatan nilai tambah produk pertanian, 2014, paper A, p 28-37.
[18] F. Maulina, N. Nelly, Hidrayani, and H. Hamid, "Parasitisasi parasitoid telur walang sangit (Leptocorisa oratorius F.) asa Kabupaten Agam dengan topografi berbeda," in Proc. Semnas tantangan dan peluang implementasi teknologi dalam perpspektif nasional, 2015, paper C-1, p. 21-25

[19] F. Maulina, N. Nelly, Hidrayani, H. Hamid, " Species diversity and parasitization of rice bug (Leptocorisa oratorius) egg parasitoids in Tanah Datar District, West Sumatra," in Proc. Semnas MBI, 2016, paper BO-12, p. 98

[20] S. Herlinda, E. Anggraini, C. Irsan, A. Umayah, R. Thalib, and T. Adam, "Spesies parasitoid Lipaphis erysimi asal Sumatera Selatan dan variasi parasitisasinya pada tumbuhan inang berbeda," J.Tropical Plant Pest and Disea., Vol. 12, pp. 111-118, 2012.

[21] M.L.T.Meiadi, T.Himawan, S.Karindah, "Pengaruh Arachis pintoi dan Ageratum conyzoides terhadap tingkat parasitisasi parasitoid lalat buah pada pertanaman belimbing," J HPT, Vol. 3, pp 44-51, 2015

[22] F. Maulina, N. Nelly, Hidrayani, and H. Hamid, " Perilaku peletakan telur walang (Leptocorisa oratorius) di pertanaman padi Sumatera Barat," in Proc. Semnas dampak perubahan iklim terhadap biodiversitas pertanian Indonesia (analisis kebijakan inter sektor), 2016, paper B3, p. 45

[23] J. Zhang, J. Huang, Y. Lu, and T. Xia, "Effects of temperature and host stage on the parasitization rate and offspring sex ratio of Aenasius bambawalei Hayat in Phenacoccus solenopsis Tinsley," PeerJ 4;e1586; DOI 10.7717/peerj.1586, 2016.

[24] N. Nelly, and D. Buchori, "Pengaruh suhu dan kerapatan inang terhadap superparasitisme oleh Eriborus argenteopilosus : Implikasi bagi pengendalian hayati," J. HPT Tropika, Vol. 16, pp 90-97, 2016.

[25] J.C. Palumbo, "Wheather and insect," J. UA.Veg IPM Update, Vol.2, 2011.

[26] F. Maulina, N. Nelly, Hidrayani, and H. Hamid, "Temperature as a key aspect in the survival of Hadronotus leptocorisae offspring," J. of Entomol, Vol. 15, pp 13-18, 2018. 